\title{
Impact of Social Media on Lifestyle and Learning Behaviour among Adolescents
}

\author{
${ }^{*}$ Mrs.Rajeswari $S$
}

\begin{abstract}
:
Objectives: To assess the impact of social media on lifestyle and learning behavior among adolescents. A quantitative Non-experimental research approach and descriptive design was adopted. The impact of social media on learning behavior revealed that were 1(1.7\%) students were mildly affected, 50 (83.3\%) students were moderately affected, o9 (15\%) were highly affected. Based on lifestyle among adolescents, the impact of social media were 40 (66.7\%) students are moderately affected and 20 (33.3\%) students are highly affected. Conclusion This study concluded that among 60 students, 40 students (66.7\%) had a moderate impact on lifestyle and in learning behaviour 50 students (83.3\%) were moderately affected due to social media.
\end{abstract}

Key words: Impact, Social Media, Life style and Learning Behaviour

\section{INTRODUCTION}

"India is the third biggest country in the world with a high social and mobile audience. Using social media website is common among the activity of today's children and adolescents. Any website that allows social interaction is considered as social media that includes face book, twitter, Skype, and video sites like YouTube and blogs. Social networking sites like facebook, twitter etc are diverting the students from their studies and bring different lifestyle among adolescents. 3 Social networking sites are affecting teenagers and young adult's lives both positive and negative ways.

Academic life is one of the areas affected. There are a number of risks associated with social media use, specifically, negative effects on mental health, cyber bullying sexting, dangers of sexual solicitation, and exposure to problematic and illegal content and privacy violations. The risk that teens face online is similar to those faced offline. However, the risk profile for the use of various types of social media depends on the type of risk, teen's use of the media, and the psychological makeup of teen using them. It is important to note that teens most at risk often engage in risky behaviour' offline and also have difficulties in other parts of their lives (Berkman 2010) 4

\section{NEED FOR THE STUDY:}

Recent research indicates that there are frequent online expressions of offline behaviors, such as bullying, cliqueforming, and sexual experimentationsthat have introduced problems such as cyberbullying, 3 privacy issues, and "sexting. 4 Other problems that merit awareness include 
Internet addiction and concurrent sleep deprivation. The social media sites are become so popular in such a short time because the information gets published in a fast way. This has actually created a lax attitude for using proper spelling as well as grammar. In fact; the students are unable to write effectively without the aid of the spell check feature of a computer. ${ }^{6}$

\section{Methodology:}

Quantitative research approach with Non-experimental descriptive design was chosen to assess the impact of social media on lifestyle and learning behaviour among 60 adolescents were selected by simple random sampling techniqueat Jothi Vallalar Higher Secondary School at Periyakalapet, Puducherry. Rating scale was used to assess the impact of social media on lifestyle and learning behavior. The tool was given to the students and 30 minutes time given for each student for completion of tool. The data were analyzed by using descriptive and inferential statistics like frequency, percentage, mean, standard deviation, and Chi-Square test

\section{DATA ANALYSIS}

\section{Distribution of Level of Impact of Social Media on Lifestyleamong Adolescents}

\begin{tabular}{|c|c|c|c|}
\hline Sl. No & Impact on lifestyle & Frequency & Percentage (\%) \\
\hline 1 & Moderate impact & 40 & $66.7 \%$ \\
\hline 2 & High impact & 20 & $33.3 \%$ \\
\hline & Total & 60 & $100 \%$ \\
\hline
\end{tabular}

It shows that the life style of majority of the students $40(66.7 \%)$ were moderately impacted and 20 students (33.3\%) were highly impacted on social media. It reveals that most of the students had negative impact on social media.

\section{Distribution of Level of Impact of Social Media on Learning Behaviour among Adolescents}

\begin{tabular}{|c|l|c|c|}
\hline S.No & $\begin{array}{c}\text { Impact on learning } \\
\text { behavior }\end{array}$ & Frequency & $\begin{array}{c}\text { Percentage } \\
\text { (\%) }\end{array}$ \\
\hline 1 & Mild impact & 1 & $1.7 \%$ \\
\hline 2 & Moderate impact & 50 & $83.3 \%$ \\
\hline 3 & High impact & 9 & $15.0 \%$ \\
\hline & Grand Total & $\mathbf{6 0}$ & $100 \%$ \\
\hline
\end{tabular}

It shows that the learning behavior of adolescents were 50(83.3\%) moderately impacted, 9 (15\%) were highly impacted, and only one student was (1.7\%) mild impacted on social media .So most of the students had negative impact on social media. 


\section{DISCUSSION:}

First objective to assess the impact of social media on lifestyle and learning behaviour among adolescents.

- Results shows that the impact on social media in learning behaviour, 01 student (1.7\%) was mildly impacted ,50 students (83.3\%) were moderately impacted and 9 students (15.0\%) were highly impacted on social media

- On lifestyle 40 students (66.7\%) were moderately impacted and 20 students (33.3\%) were highly impacted on social media.

Second objective to associate the impact of social media on lifestyle and learning behaviour among adolescents withselected Demographic variables.

- On learning behaviour, the study shows that students using social media mainly for social networking (0.074\%) for learning behaviour.

- In lifestyle there is significance in residential area $0.066 \%$ and education of father $0.016 \%$ and education of mother 0.216\%.Television has adverse effect on students. In television usage are highly impacts on social media $0.06 \%$ on lifestyle.

\section{RECOMMENDATIONS:}

A similar comparative study can be conducted on students between the Private and Government school to assess the impact of social media on lifestyle and learning behaviour.

\section{CONCLUSION:}

This study viewed benefits, positive and negative impacts of social networking sites and how the social media influence youth in their lifestyle and learning behavior. Social media enable youth to raise their voice against social issues and are or upload information for the welfare of the society. Since Social media can provide all the ways and means to develop personal and social aspects, the young people have to explore the potentialities of these sites. Even though it creates a few negative impacts on youth, we cannot think of a world without these sites today. So, corrective and preventive measures should be taken towards these negative effects and the young people should be well educated and must have proper awareness regarding such problems of Social media.Social media influence the lifestyle of youth so that the brands and companies can exploit the space of Social Networking Sites to create loyalty among youth. If the Social media promote a healthy life style through its posts, videos and messages, that will help to develop a healthy young generation.

\section{REFERENCES:}

1. Rithikam\&Saraselvaraj. Impact Of Social Media On Students Academic Performance."International Journal on Logistics \& Supply Chain Management Perspective"; Volume2; Issue 4. 2014. Page No.636-640

2. Marilyn J.Hockenberry\& David Wilson. Wong's; "Essential Of Pediatric Nursing" ( $8^{\text {th }}$ Edition). Philadelphia,Elesevier Publication,2010. Page No.506

3. Heyama,Al -Tarawne. The Influence Of Social Networking On Students Performance. "Journal Of Emergng Trends InComputing Information Science"; Volume 5,Issue.3; 2014.Page No;200-205

4. Liju James \&Sivakumar. Assess The Impact Of Multimedia Usage On Behaviour Pattern Of Pre-University College Students; "Asian Jorunal Of Nursing Education And Research"; Volume 5, Issue 2; 2014.PageNo; 180-182

5. B.T Basavanthappa; "Textbook Of Nursing Research" (2 ${ }^{\text {nd }}$ Edition). Jaypee Publication; 2007. Page: 2

6. www.hongkiat.com $>$ blog $>$ science 